\title{
Mothers and Sons: Representing Motherhood in Blood Wedding and Mother Courage and Her Children
}

\author{
Sabrine Saleh ${ }^{1}$ (D) $\triangle$ and Lina Saleh ${ }^{2}$ (D) \\ ${ }^{1}$ Ph.D. Candidate, Academic Instructor Department of Basic Sciences, Middle East University, Amman-Jordan \\ ${ }^{2}$ Ph.D., Full-time Lecturer Department of English Language and Literature Al-Balqa Applied University, Salt-Jordan \\ $\triangle$ Corresponding Author: Sabrine Saleh, E-mail: sabreena.saleh@yahoo.com
}

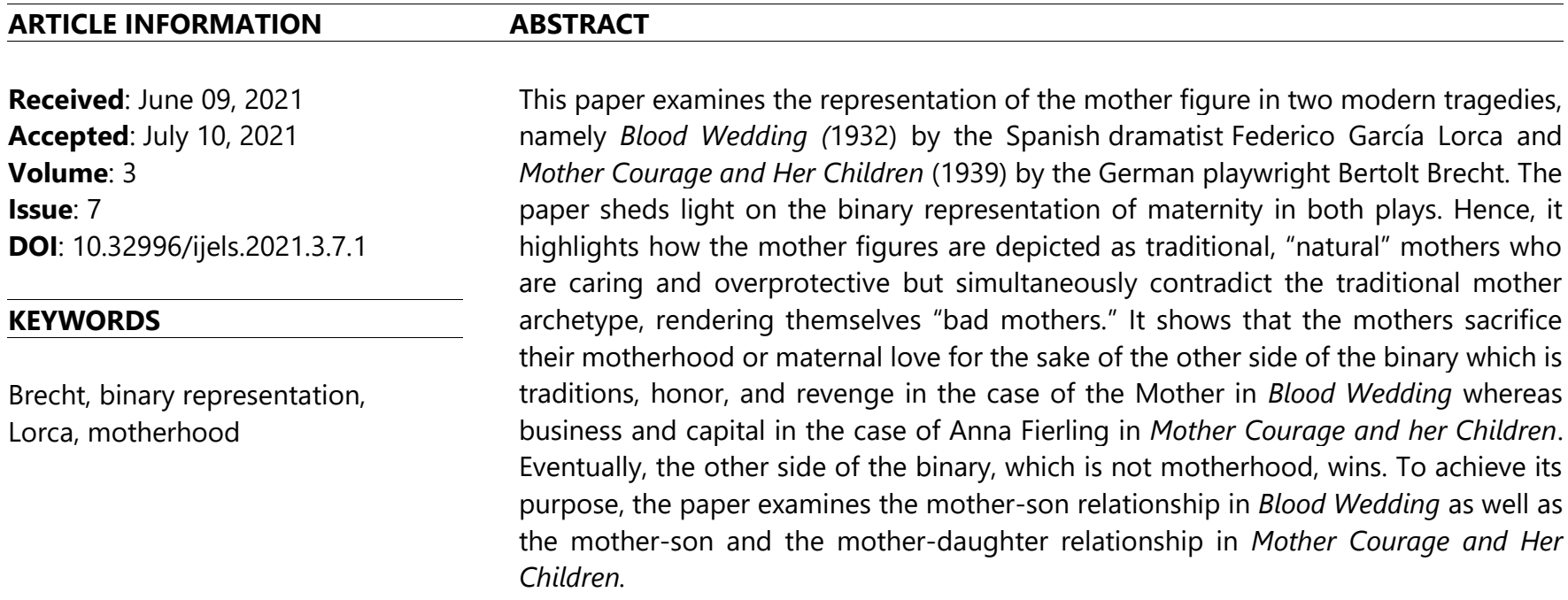

\section{Introduction}

This paper sheds light on the binary representation of maternity in Federico García Lorca's Blood Wedding (1932) and Bertolt Brecht's Mother Courage and Her Children (1939). It demonstrates that the mother figures in both plays are depicted according to the traditional mother archetype as caring and overprotective but simultaneously contradict it by sacrificing their motherhood or maternal love. Hence, the two mothers forfeit motherhood for the other side of the binary: traditions, honor, and revenge in the case of the Mother in Blood Wedding whereas business and capital in the case of Anna Fierling in Mother Courage and her Children. Eventually, the other side of the binary, which is not motherhood, wins.

\section{Discussion}

As soon as Act One starts in Blood Wedding, the image of the overprotective mother is established. The play starts with a conversation between the Bridegroom and the Mother. The Bridegroom tells his mother that he is going out to the vineyard to cut grapes. This makes his mother anxious, as she curses the invention of knives: "Knives, knives...Curse them all, and the wretch who invented them...(5), and she also curses "whatever can cut through a man's body (ibid). The conversation reveals that she is being hysterical towards knives since they remind her of death and violence. She reminisces about the death of the Bridegroom's father and brother, both of whom were murdered by members of the Felix family. The Mother says that she does not like it when her son leaves the house since this means the possibility of losing her last surviving child. In this regard, she says: "I wish you were a woman. You'd not go to the river now, and we would sit and sew" (6). In this scene, she is overprotective and so worried about his safety to the extent that she warns him against using the knife peacefully in the field and wishes he were a woman.

The Mother's obsession with and lamentation over the past seems to be partial because she is concerned about the future of her son at the beginning of the play. Throughout the play, the Mother's talk revolves around her past loss and her unwillingness to forget what the Felixes did to her loved ones. This results in her subsequent anxiety about a future loss. Nevertheless, she agrees

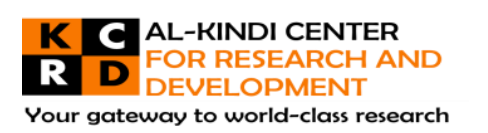

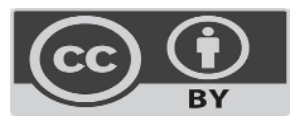

Published by Al-Kindi Center for Research and Development. Copyright (c) the author(s). This open access article is distributed under a Creative Commons Attribution (CC-BY) 4.0 license 
to go along with her son's marriage even after finding out that the Bride was once romantically involved with Leonardo, the last free member of the Felix family. Moreover, she decides not to tell her son this so as not to ruin his happiness.

This overprotective attitude and unconditional love soon start to change. The encounter between the Mother and the Bride's Father shows that she agrees to the marriage not only to please her son or to succumb to his demand of marrying a lady he has chosen as a wife but also due to the financial gains the marriage will ensue. Both parents are delighted by the transactional nature of the wedding, seeing it as a union that will bring children and riches. Consequently, it appears to be a marriage of convenience as "they'll unite two fine fortunes" (18) and it will produce children who are needed as "unpaid labour" for the land (45).

After the Bride's elopement with Leonardo, the Mother succumbs to the allure of violence and revenge, willingly sacrificing her only son. Although the mother condemns violence, she is quick to encourage her son to violently seek revenge. Her desire for vengeance is twofold: to save the family's honor and to avenge the death of her husband and son by killing Felix. The elopement of the Bride is rather scandalous, particularly in a rural society. Since "she's my son's wife now," the Mother urges the men to "Hunt them! Take every road. The hour of blood is here once more" (55). In "Sterility and its Implications in Federico Garcia Lorca's Blood Wedding," Shibashish Purkayastha argues that "The Mother is very much a part of the strictest codes of honour and marriage that are so much a part of the Spanish system" (26). Consequently, she sends the only son who will carry the legacy of the family for his inevitable death. In this respect, Purkayastha states that

the Mother sends her son to bring his wife back to save her family's honour. To send her son off is certain death for him, annihilating any hope for the future for which she has planned, but at the same time, to keep him with her would annihilate the family honour and name. Her choice is made almost instantly in favour of death, knowing that only her honour will be left. (27)

These concerns have been quite evident even before the elopement. The Mother questions the reputation and honour of the Bride only because of the Bride's previous engagement to another man. The First Woodcutter seems to refer to the Mother when he says: "They tried to deceive themselves, but in the end, blood proved stronger" (56). The pull of motherhood is in no way stronger than the pull of blood for the Mother.

The mother brings her son's doom not only because she wants to save his honor but also because she seeks revenge from the Felix family by killing the only Felix man who has not been imprisoned, for Leonardo was only eight when his family members killed the Bridegroom's father and brother. From the very beginning, she complains that imprisonment is not a harsh enough punishment. Her latent desire for violence is brought to the surface as she advocates and yearns for violence at this point. Hence, the family's history with the Felixes is another reason why the Bridegroom must find Leonardo and take his revenge. In fact, the Mother seems to represent what the First Woodcutter says in this regard: "Better to die of loss of blood than live with poison in your veins" (56). The Mother seems to be haunted by the poisonous past of blood which paradoxically only blood can heal. The play ends in tragedy because the Mother adopts the same brutal mentality of the past, thus perpetuating the feud. Had she maintained her hatred for knives and killing, tragedy could have been avoidable. In fact, she seems to wish to shed the "Only bad blood there"(44) in Leonardo's veins even if her son's blood is going to be likewise shed.

When the Bridegroom dies, the Mother feels absurdly liberated. Upon hearing the news of his death, she mourns his loss saying: "[b]ut now my son is an armful of withered flowers. Now my son is a dark voice" (73). However, she expresses how his death is quite a relief as she realizes that she no longer has to worry about anyone attacking her loved ones:

Here. Here, where I am. And in peace. They're all dead now.

I'll be able to sleep at night, sleep free of the fear of guns and knives. Other

women will lean sleepless from their windows, drenched by the rain, to

catch sight of their sons' faces. Not I. My dreams will be of a cold dove of

marble carrying flowers of frost to a graveyard. (ibid)

This perfectly reflects her dualism as she vehemently seeks revenge while simultaneously being a bereaved mother. The Mother is torn between the mother and the avenger. She expresses this dilemma herself by saying "I don't understand it myself. Did I not love my son enough? (74).

By the same token, Mother Courage and Her children depict a mother who is trapped between her materialistic pursuits and her motherhood. Anna Fierling's desire to pursue capital as a merchant and war profiteer comes at the expense of her children's lives. Fierling is known by the nickname "Mother Courage." Her very nickname expresses her dualistic representation as a mother and a courageous capitalist. In the first scene when she is asked why she is nicknamed "Mother Courage," she explains by saying, 
"They call me Courage because I was scared of financial ruin" (15). In this sense, her courage stands for striving for success and thriving of capital. Her courage, however, battles with her motherhood throughout the play.

Mother Courage uses her courage to provide for her family in the first place. The play starts in seventeenth-century Sweden, with Courage running a canteen business during the Thirty Years' War (1618-1648). The Thirty Years' War between Catholics and Protestants was one of the bloodiest wars in European history. For Courage though, the war is a blessing rather than a misfortune: "This is war. A nice source of income, I must say!" (80). Courage follows armies, trying to buy goods and sell them to the locals. She profiteers from war to support her two sons Eilif and Swiss Cheese as well as her daughter, Kattrin. Her love for business and profiteering at the beginning of the play does not battle with her desire to be a good mother.

In the first scene, Mother Courage expresses how she wishes to keep her children away from harm by keeping them involved with her business rather than war. She is stopped on the road by a Sergeant and a Recruiter for the Swedish army. When her son, Eilif, expresses his desire to attack the Recruiter for insulting him and his brother, Courage stops him saying, "Stay here. You're never happy till you're in a fight. He has a knife in his boot and he knows how to use it" (18). Her fear of the knife reminisces the Mother's in Blood Wedding. Both mothers try to protect their sons from knives' attacks but they are ready to use knives and violence to defend their children's honor or lives. When the Recruiter tries to take Eilif as a soldier, she tells Swiss Cheese, "Run and tell everybody they're trying to steal your brother! (She draws a knife.) Yes, just you try, and I'll cut you down like dogs!" (19). Fierling's motherly instinct is so strong here since she is ready to commit a murder to protect her child.

Although Fierling seems to be a good mother at times, she loses her three children while she is away in business. By the end of scene one, the Sergeant exploits her love for capital and distracts her by buying belt buckles in order to give chance to the Recruiter to tempt Eilif to be enlisted in the army. Unfortunately, she realizes this only when it is too late and her son is gone. Even later when Eilif tries to see her before he is executed for killing peasants in peacetime, she is also away in business. Because peace is declared, Courage fears her business is ruined because she will not be needed as a canteen lady during peacetime. Hence, she rushes to sell the goods that the Chaplain has advised her to buy believing that war will go on forever. Thus, Mother Courage misses the chance of seeing her son before he dies, and surprisingly enough, till the end of the play, she does not even find out about Eilif's death.

Her second son, Swiss Cheese, is the most obvious example of how her love for capital is privileged over her children's lives. Swiss Cheese becomes a paymaster, carrying around the army's cash in a moneybox. When the Catholics invade, Mother Courage and her friends decide to pretend they are Catholics, but Swiss Cheese worries that he will be found out if they catch him with his Protestant moneybox. Therefore, he decides to hide it by the river. Catholic spies capture him in the act and arrest him. Courage tries to sell her wagon to a friend of hers named Yvette in order to get enough money to bribe the Catholics to release her son, but she hesitates when she realizes it will leave her with nothing to live on. Although Yvette tells her that "Swiss Cheese's life's at stake," she hesitates to tell her that "we live of the wagon" (53). She is totally stripped of motherly feelings when she says: "A hundred and twenty or no deal" (56), as if her son's life is a transaction which she can bargain. Eventually, because she delays too long, she misses the opportunity of saving her child's life for two hundred guilders. As a result, the Catholics shoot Swiss Cheese eleven times. Moreover, when they bring her his body for identification, she tells the soldiers that she does not know him in order not to think she is connected with him, and thus he ends up thrown in the "carrion pit" (59).

Her daughter Kattrin is also a victim of her greed, selfishness, and love for capital. Mother Courage shows motherly love for Kattrin when she is around. For example, when the Catholics attack, she covers her face with ashes and prevents her from wearing the red boots in order not to be turned into a prostitute to the soldiers like Yvette. However, the harm she causes her is way more destructive. Several incidents in the play testify that Courage's business is the reason behind her daughter's misfortune and tragic end. For instance, when Courage sends Kattrin to town to bring some goods, Kattrin gets attacked by soldiers on her way back, leaving a permanent scar on her face, destroying any possibility of a future marriage. One might also argue that even her dumbness might be caused by the absence of her mother and that is when a "soldier stuck something in her mouth when she was little" (80). Another incident is when Kattrin dies and her mother is unsurprisingly off doing business. This happens when the Catholics start a secret, nighttime attack on the town. Kattrin figures out what is going on and bangs on a drum that she takes from the wagon until the townspeople are alerted. Catholic soldiers threaten and beg her to stop drumming, but she refuses to stop. Eventually, they shoot her dead.

At the end of the play, despite the loss of her three children, Mother Courage does not give up her business as a canteen woman. After Courage sings a lullaby for dead Kattrin and pays the peasants for her burial, she expresses how she is now ready to get back to business alone: "Hopefully I'll manage to pull the wagon alone. I bet I can do it, not much in it anymore. I have to get back in business" (116). Apparently, in the case of Mother Courage, to be a good mother and successful merchant are incompatible especially in the context of war. Mother Courage's profit from war comes at the expense of her three children's loss. In this respect, the Sergeant's statement at the beginning of the play is quite relevant and foreshadowing: "When a war gives you all you earn, one day it may claim something in return!" (24). Although her successful business at many points in the play has resulted in the loss of 
her children, ironically she ends up penniless and childless. Despite her double loss, she decides to go on and start anew as if nothing happened. The play presents war as an ultimately meaningless venture, in which no one ever wins even war-profiteers.

As far as Brecht's "epic theatre" is concerned, some characteristics of this theatre support the argument. One characteristic is the "alienation effect" which the dualism of the mother character creates. Consequently, the audience is confused and wavers between sympathizing with the mother and condemning her. In fact, Brecht did not want the audience to sympathize with her but his intention was to warn the audience against the dangers that the pursuit of capital ensue. In an online article titled "Brecht's Mercenary, Mother Courage Turns 75," Katie Baker notes that Brecht's audiences "were missing the point of his Verfremdungseffekt, that breaking of the fourth wall which was supposed to make the masses think, not feel, in order to nudge them in a revolutionary direction." She also quotes Brecht as lamenting "The (East Berliner) audiences of 1949 did not see Mother Courage's crimes, her participation, her desire to share in the profits of the war business; they saw only her failure, her sufferings." Brecht's goal was to highlight Mother Courage's faulty response to war rather than pathetic circumstances caused by war.

\section{Conclusion}

This paper shows that the mother figures in Gorki's Blood Wedding and Brecht's Mother Courage and Her Children are characterized by dualism; although caring and protective, they are ready to sacrifice the lives of their children for personal gains, materialistic or otherwise. The Mother in Blood Wedding encourages her son to commit murder to save his honor and avenge his brother and father's death, knowing that he will lose his own life in the process. Similarly, Mother Courage loses her three children while trying to gain profit in business. The two mothers sacrifice one side of the binary which is motherhood for the sake of the other side which contradicts "natural" motherhood. Hence, they contradict the traditional mother archetype that depicts the mother as a sacrificial figure who would sacrifice her personal interests for the sake of her children, not vice versa.

\section{References}

[1] Baker, K. (2014)."Brecht's Mercenary Mother Courage Turns 75." Daily Beast: 10 September.

[2] https://www.thedailybeast.com/brechts-mercenary-mother-courage-turns-75

[3] Brecht, B. (1939). Mother Courage and Her Children. London: Methuen Drama. http://ciml.250x.com/archive/communists/brecht/english/mother_courage.pdf

[4] García, Lorca F. (1932). Blood Wedding. Newcastle upon Tyne: Bloodaxe. http://shiraz.fars.pnu.ac.ir/portal/file/?970429/Blood-Wedding-Original.pdf

[5] Purkayastha, S."Sterility and its Implications in Federico Garcia Lorca's Blood Wedding." Literature and Herald, Vol. 5, Issue 3 (October 2019). 